\title{
Two novel ligand-independent variants of the VEGFR-1 receptor are expressed in human testis and spermatozoa, one of them with the ability to activate SRC proto-oncogene tyrosine kinases
}

\author{
Belen Alvarez-Palomo ${ }^{1, *}$, Carme Barrot-Feixat ${ }^{2, *}$, Helena Sarret ${ }^{1}$, Jordi Requena ${ }^{1}$, \\ Montserrat $\mathrm{Pau}^{3}$, Jose-Manuel Vidal-Taboada ${ }^{4}$, Rafael Oliva, ${ }^{5,6}$, Josep-Lluis \\ Ballesca7, Michael J. Edel ${ }^{1,8,9}$ and Jovita Mezquita-Pla ${ }^{1}$ \\ ${ }^{1}$ Molecular Genetics and Control of Pluripotency Laboratory, Department of Biomedicine, Biomedical Research Institute \\ August Pi i Sunyer (IDIBAPS), Institute of Neurosciences, Faculty of Medicine and Health Sciences, University of Barcelona, \\ Barcelona, Catalonia, Spain \\ ${ }^{2}$ Forensic Genetics Laboratory, Medicine Department, Faculty of Medicine and Health Sciences, University of Barcelona, \\ Barcelona, Catalonia, Spain \\ ${ }^{3}$ Molecular Genetics Laboratory, Department of Biomedicine, Faculty of Medicine and Health Sciences, University of Barcelona, \\ Barcelona, Catalonia, Spain \\ ${ }^{4}$ Peripheral Nervous System, Neuroscience Department, Vall d'Hebron Research Institute (VHIR), Barcelona, Catalonia, Spain \\ ${ }^{5}$ Molecular Biology of Reproduction and Development Laboratory, Biomedical Research Institute August Pi i Sunyer (IDIBAPS), \\ Department of Biomedicine, Faculty of Medicine and Health Sciences, University of Barcelona, Barcelona, Catalonia, Spain \\ ${ }^{6}$ Biochemistry and Molecular Genetics Service, Biomedical Diagnostic Centre, Hospital Clinic, Barcelona, Catalonia, Spain \\ ${ }^{7}$ Clinic Institute of Gynaecology, Obstetrics and Neonatology, Hospital Clinic, Barcelona, Catalonia, Spain \\ ${ }^{8}$ International Research Fellow, Victor Chang Cardiac Research Institute, Sydney, New South Wales, Australia \\ ${ }^{9}$ Senior Research Fellow, University of Western Australia, School of Medicine and Pharmacology, Harry Perkins Research \\ Institute Centre for Cell Therapy and Regenerative Medicine (CCTRM), Perth, Western Australia, Australia \\ *First authors
}

Correspondence to: Jovita Mezquita-Pla, email: jmezquita@ub.edu, jovitamezquita@gmail.com Keywords: ligand-independent intracellular iVEGFR-1 isoforms; mature testis; spermiogenesis; SRC activation; fertility Received: July 17, $2019 \quad$ Accepted: September 24, $2019 \quad$ Published: October 08, 2019

Copyright: Alvarez-Palomo et al. This is an open-access article distributed under the terms of the Creative Commons Attribution License 3.0 (CC BY 3.0), which permits unrestricted use, distribution, and reproduction in any medium, provided the original author and source are credited.

\section{ABSTRACT}

The vascular endothelial growth factor receptor 1 (VEGFR-1) family of receptors is preferentially expressed in endothelial cells, with the full-length and mostly the soluble (sVEGFR-1) isoforms being the most expressed ones. Surprisingly, cancer cells (MDA-MB-231) express, instead, alternative intracellular VEGFR-1 variants. We wondered if these variants, that are no longer dependent on ligands for activation, were expressed in a physiological context, specifically in spermatogenic cells, and whether their expression was maintained in spermatozoa and required for human fertility. By interrogating a human library of mature testis CDNA, we characterized two new truncated intracellular variants different from the ones previously described in cancer cells. The new isoforms were transcribed from alternative transcription start sites (aTSS) located respectively in intron-19 ( $i_{19}$ VEGFR-1) and intron-28 ( $i_{28}$ VEGFR-1) of the VEGFR-1 gene (GenBank accession numbers JF509744 and JF509745) and expressed in mature testis and spermatozoa. In this paper, we describe the characterization of these isoforms by RT-PCR, northern blot, and western blot, their preferential expression in human mature testis and spermatozoa, and the elements that punctuate their proximal promoters and suggest cues for their expression in spermatogenic cells. Mechanistically, we show that $i_{19}$ VEGFR-1 has a strong ability to phosphorylate and activate SRC proto-oncogene non-receptor tyrosine kinases and a significant bias toward a decrease in expression in patients considered infertile by WHO criteria. 


\section{INTRODUCTION}

During meiotic and post-meiotic stages of spermatogenesis, the genome is reprogrammed prior to packaging. Simultaneously, new mRNAs responsible for active and precise synthesis of proteins are transcribed with stage specific precision. Selected transcripts and proteins, essential for spermatozoa activity, fertilization or embryo development are retained in the spermatozoa $[1,2]$.

Many spermatogenic transcripts are produced from alternative transcription start sites and alternative splicing of the $5^{\prime} \mathrm{UTR}$. Although these mRNAs may code for proteins identical to their somatic counterparts, they often differ, from the corresponding somatic transcripts, in regulatory potential $[3,4]$.

Protein tyrosine kinases (PTKs) are key factors regulating spermatogenesis, essential for differentiation, migration, adhesion, spermatid shaping, motility and capacitation. In addition to the general requirement for PTKs, normal spermatogenesis and spermiogenesis also seem to be dependent on the expression of truncated isoforms [5]. Truncated proteins, many of them protein kinases, either coexist with full-length partners or replace them. For example, the KIT proto-oncogene receptor tyrosine kinase is highly expressed in spermatogonia and is replaced by the truncated-intracellular KIT version (TrKIT) during spermiogenesis [6-9]. Interestingly, there is a high degree of similarity between VEGFR-1 and KIT, and between $i_{19}$ VEGFR-1 and Tr-KIT.

Vascular endothelial growth factor receptor 1 (VEGFR-1), also known as FLT-1 (fms related tyrosine kinase 1) is a high-affinity and low-activity (relatively to VEGFR-2) tyrosine kinase receptor of the vascular endothelial growth factor VEGF-A, and binds selectively to ligands VEGF-B and placental growth factor (PIGF) [10-13]. Expression of the VEGFR-1 receptor occurs mainly in endothelial cells, but also takes place in different types of non-endothelial cells [14, 15], including mouse spermatids and spermatozoa [16].

VEGFR-1 in humans consists of 30 exons spanning more than $193 \mathrm{~kb}$ [17]. Two extracellular soluble isoforms, sVEGFR-1 and s14VEGFR-1, end in exons generated by extending into intron 13 (sVEGFR-1) or jumping into intron 14 (s14VEGFR-1) [18, 19]. In addition, we have characterized several intracellular isoforms of VEGFR-1 expressed in cancer cells [20].

In mouse [16], the vascular endothelial growth factor receptor 2 (VEGFR-2), the high-activity and lowaffinity receptor for VEGF-A, comparatively to VEGFR-1 (also known as KDR, kinase insert domain receptor) is expressed in type A spermatogonia, while VEGFR-1 is not expressed until the pachytene spermatocyte and round spermatid stages. There is no knowledge of the specific VEGFR-1 isoforms expressed in mouse spermatogenic cells, and contrary to human [20], no truncated isoforms of the VEGFR-1 receptor are known to be expressed.
In this paper, we have identified two intracellular isoforms of the VEGFR-1 receptor in mature testis and spermatozoa. We have named them $\mathrm{i}_{19}$ VEGFR-1 and $\mathrm{i}_{28}$ VEGFR-1, as they start transcription in intron 19 and 28, respectively, and we have characterized them by sequencing, RT-PCR, northern and western blot. Mechanistically, we have demonstrated, using binding experiments and transfection of recombinant plasmids in CHO and HEK293 cells, that $\mathrm{i}_{19}$ VEGFR-1 is able to bind and strongly phosphorylate and activate SRC protein kinases.

As a preliminary study, due to sample scarcity and the lack of confident parameters for fertility, we have analyzed by Real time-PCR, the expression of both isoforms in samples of astenozoospermic, oligozoospermic or oligoastenozoospermic patients relative to normozoospermic samples (WHO parameters) [21]. We wanted to assess the predictive potential of their expression as a marker for male infertility, a major problem worldwide because of inaccurate diagnosis, much dependent on empirical evidence and unreliable parameters.

We have also explored by an in silico approach, taking advantage of the huge quantity of available data in well-documented networks and testis cell lines, the chromatin landscape and the response element present in the corresponding proximal promoters around the TSS, of both isoforms. The reported results showed a relatively open chromatin configuration, punctuated by activating marks signatures and regulatory DNA sequence elements, which may allow for transcription in post-meiotic cells.

Taken together, the two $i_{19}$ VEGFR- 1 and $i_{28}$ VEGFR-1 isoforms described in this paper may represent haploid cell specifically expressed transcripts that function as convenient ligand-independent intracellular factors with interest in fertility and fertilization.

\section{RESULTS}

\section{Identification of two novel intracellular truncated C-terminal isoforms of VEGFR-1}

A search by Rapid amplification of cDNA ends (RACE5' and RACE3') for truncated intracellular isoforms of the VEGFR-1 receptor, failed to detect previously characterized intracellular isoforms [20] of the VEGFR-1 receptor in mature human testis and spermatozoa. We also interrogated a mouse mature testis cDNA library and could not find any truncated isoform of the VEGFR-1 receptor. In contrast, the same analysis, by rapid amplification of c-DNA ends (RACE), RACE5' and RACE3', of a mature testis human cDNA library, allowed us to obtain two novel truncated intracellular isoforms variants of the VEGFR-1 receptor. We named these intracellular isoforms $i_{19}$ VEGFR-1 and $i_{28}$ VEGFR-1, the number indicating the intron where the aTSS is located (Figure 1).

Both isoforms lack the sequences for extracellular domains, transmembrane domain and either, part of the 
kinase domain ( $\mathrm{i}_{19}$ VEGFR-1) or the whole kinase domain, leaving only a sequence coding for a C-terminal tail of 85 amino acids in the case of $i_{28}$ VEGFR-1. Both isoforms incorporate new leader 5'UTR sequences (Figure 1A). For the 3'UTR, we obtained a sequence of 675 nucleotides, finishing in a rich poly (A) sequence. This $3^{\prime} \mathrm{UTR}$ is much shorter than the canonical VEGFR-1 3'UTR observed in endothelial cells. Northern blot reinforced the predominance of this $3^{\prime} \mathrm{UTR}$ (as mentioned later), also showing the existence, in much lower amounts of the longer canonical 3'UTRs.

Isoform $i_{19}$ VEGFR-1 starts at nucleotide 1,200 of intron 19 of the full-length VEGFR-1 receptor, in a $\mathrm{T}$ nucleotide that is followed by a sequence element, where 19 nucleotides out of 21 matches the p53 sequence element [22] (red in Figure 1A). This motif can form a hairpin structure (Figure 1A). The first exon of this isoform has a conserved splice site (gt) that jumps to the second exon acceptor site (ag), generating a VEGFR-1 isoform of 12 exons, the last 11 corresponding to exons 20 to 30 of the full length VEGFR-1. The 5'UTR of the new isoform, is 129 nucleotides long, and shows two out of frame uORFs (Figure 1A).

The putative $\mathrm{i}_{19}$ VEGFR-1 transcript encodes a protein of 433 amino acids, from amino acid 906 to amino acid 1,338 of the full-length VEGFR-1 receptor, with a predicted molecular weight of $49.4 \mathrm{kDa}$; isoform $\mathrm{i}_{19}$ VEGFR-1 conserves 253 of the 332 amino acids of the kinase domain. It has lost most of the ATP-binding domain, but it conserves the phosphotransferase site as well as eight tyrosine-phosphorylation sites (Figure 1B and Figure 2).

Isoform $i_{28}$ VEGFR-1 starts at nucleotide 308 of intron 28 of the full-length VEGFR-1, in a very rich polypyrimidine stretch. The first exon of this isoform has a conserved splice site (gt) that jumps to the second exon acceptor site (ag), generating a small VEGFR-1 isoform of 3 exons, the last 2 corresponding to exons 29-30 of the full-length VEGFR-1. The 5'UTR of the new isoform is 135 nucleotides long. The putative $i_{28}$ VEGFR- 1 encodes a protein of 85 amino acids, from amino acid 1,254 to amino acid 1,338 of the full-length VEGFR-1 receptor, with a molecular weight of $9.5 \mathrm{kD}$. The $\mathrm{i}_{28}$ VEGFR-1 isoform lacks the entire kinase domain (Figure 1B), and conserves the last 3 phosphotyrosine sites (Figure 2).

\section{Expression of $i_{19}$ VEGFR- 1 and $i_{28}$ VEGFR-1 isoforms in human mature testis, cryptorchidic testis, spermatozoa, and HUVEC cells, relative to the expression of canonical VEGFR-1, full- length and soluble variants, and in samples with accepted or altered WHO 2010 parameters}

We analyzed the expression of $i_{19}$ VEGFR-1 and $\mathrm{i}_{28}$ VEGFR-1 and of full-length VEGFR-1, sVEGFR-1 and s14VEGFR-1 isoforms, by northern-blot and/or semi-quantitative manual PCR, and Real-Time PCR, in human mature testis, cryptorchidic testis, HUVEC cells (a positive control for VEGFR-1), and human spermatozoa.

Figure 3 shows the northern-blot results obtained from mature testis, cryptorchidic testis and endothelial HUVEC cells using total RNA and a probe from the kinase region (Table 1). The pattern of expression in testis differs entirely from endothelial cells. In HUVEC cells, fulllength VEGFR-1 mRNA is detected as a band of $\approx 6.9 \mathrm{~kb}$, and a second band at $\approx 4.7 \mathrm{~kb}$, corresponds to a truncated isoform. Cryptorchidic testis, devoid of spermatogenic differentiating cells, shows only, a very faint band of $\approx 6.9 \mathrm{~kb}$. The pattern of expression in mature testis correspond to bands of $\approx 4.7 \mathrm{~kb}, \approx 2.6 \mathrm{~kb}$ and $\approx 1.5 \mathrm{~kb}$, all of them compatible with the expected sizes of $i_{19}$ VEGFR-1 and $\mathrm{i}_{28}$ VEGFR-1 transcript isoforms, having different 3'UTR lengths, but preferentially using the short 3'UTR of 675 nucleotides obtained by RACE3' (3'S, Figure 3). The northern pattern results are also in accordance with the relative expression of transcripts obtained by quantitative RT-PCR.

By semi-quantitative, as well as by Real-Time PCR, we detected significant levels of $i_{19}$ VEGFR-1 and $\mathrm{i}_{28}$ VEGFR-1 transcripts only in mature testis and spermatozoa (Figure 4A-4D). Full-length and both soluble forms, sVEGFR-1 and s14VEGFR-1, were also detected by PCR amplification in testis and spermatozoa, although at levels much lower than in HUVEC cells (Compare Figure $4 \mathrm{~B}$ and $4 \mathrm{D}$ to $4 \mathrm{E}$ ).

Isoforms $i_{19}$ VEGFR-1 and $i_{28}$ VEGFR-1, as detected by Real-Time PCR, showed higher expression in spermatozoa than in testis, suggesting preferential expression in haploid spermatogenic cells. (Compare Figure 4B with Figure 4D).

Quantitative real-time PCR of $i_{19}$ VEGFR-1 and $\mathrm{i}_{28}$ VEGFR-1 mRNA from spermatozoa obtained from astenozoospermic, oligozoospermic or oligoastenozoospermic semen samples revealed statistically significant lower levels of $i_{19}$ VEGFR-1 expression compared to normozoospermic semen samples (Figure 4F). Expression of $i_{28}$ VEGFR-1 was also investigated but, although there was a tendency towards decreased levels in infertile samples, they were no statistically significant (data not shown).

Western blotting was employed to determine whether $i_{19}$ VEGFR-1 and $i_{28}$ VEGFR-1 transcripts were translated into proteins.

Figure 5 shows the protein corresponding to the $\mathrm{i}_{19}$ VEGFR-1 isoform. It was detected in spermatozoa using an anti-VEGFR-1 antibody from the C-terminal of the protein (Santa Cruz, see materials and methods and Table 2). Binding of the antibody at the corresponding size of $49 \mathrm{kD}$ competed with an epitope specific blocking peptide (Santa Cruz) from the same region indicating the specificity of the western blot bands shown in Figure 5. The peptide corresponding to ${ }_{\mathrm{i} 28}$ VEGFR-1, expected as a $9.5 \mathrm{kD}$ band, was not as consistently detected. It appears as a faint band suggestive of a quite unstable peptide. The cropped 


\section{${ }_{119}$ VEGFR-1 and ${ }_{i 28}$ VEGFR-1 TRANSCRIPTS and PROTEINS}

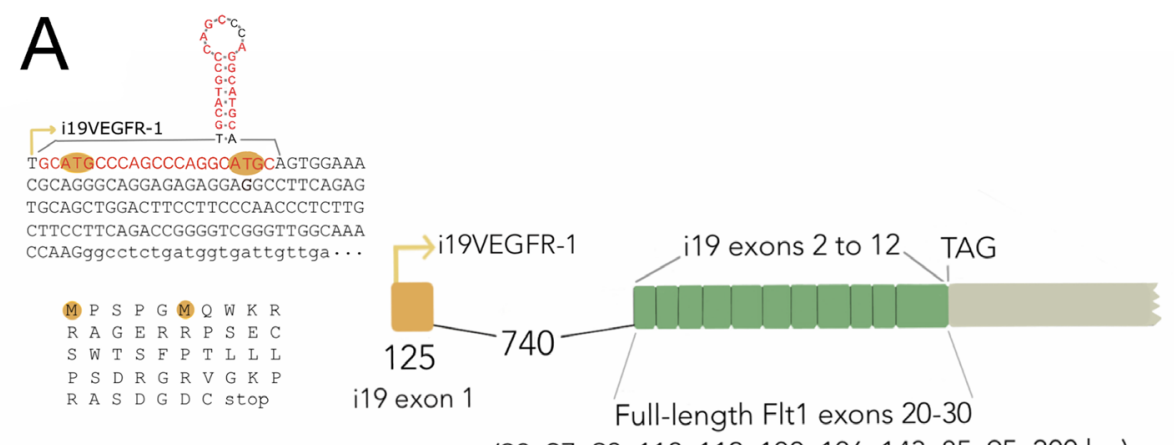

$(90,97,98,110,112,100,106,143,85,95,200 \mathrm{bp})$ \begin{tabular}{l}
$\longrightarrow$ i28VEGFR-1 \\
TATGCTCCTTTCCCCTGAGGTTCTACAGATTG \\
\hline AACAGCTGTGTTCCTACCCAATCACAATGGGA \\
GAAGCTAACCAGTATAGCCTGGCAAACAAGAG
\end{tabular}

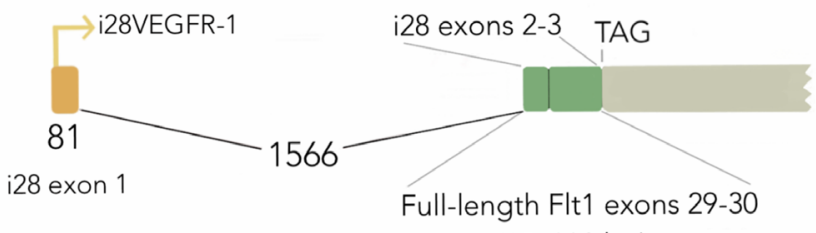

$(95,200 \mathrm{bp})$

B

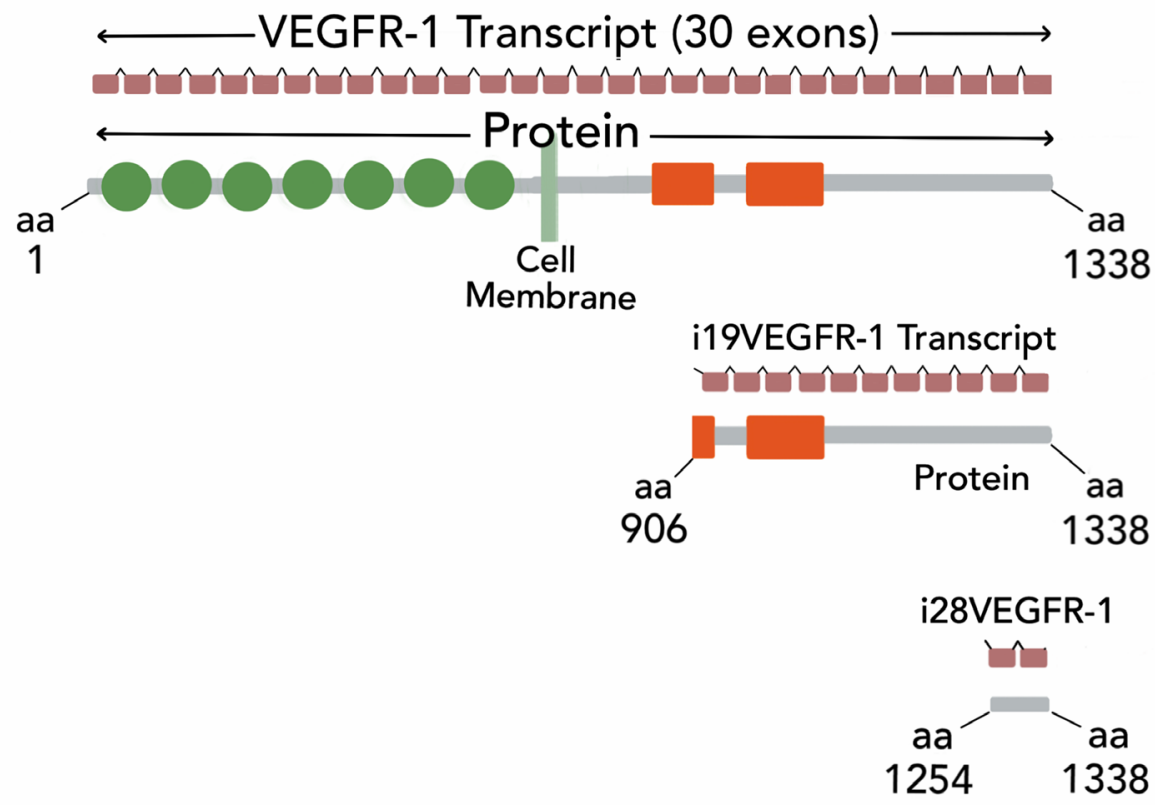

Figure 1: (A) Exon assembly of $i_{19}$ VEGFR-1 and $i_{28}$ VEGFR-1 isoforms indicating start of transcription (arrows), specific first exon (yellow) and intron 1 (broken line with nucleotide's number), followed by the exons shared with the full-length receptor, and the stop codon (TAG). Top left, whole exon 1 (capital letters) and first 22 nucleotides of exon 2 (lower case) of $i_{19}$ VEGFR-1. Exon 1 starting with the p53 sequence element (in red), is depicted with the putative hairpin structure. The open reading frames (uORF) are indicated, highlighting the ATG codon, as well as the non-in-frame putative peptides in the leader 5'UTR sequence. Below, the complete first exon of $i_{28}$ VEGFR-1 with the polypyrimidine stretch (underlined) at the start of transcription (arrow). (B) Gene and protein assembly. The 30 exons (small brown rectangles) spanning the full- length VEGFR-1 receptor, or the eleven ( $i_{19}$ VEGFR-1) and two $\left(i_{28}\right.$ VEGFR-1) coding exons, are shown on top of each schematic protein. From top to bottom, full-length protein of 1,338 amino acids (aa), $i_{19}$ VEGFR-1 intracellular isoform of $432 \mathrm{aa}$, and $\mathrm{i}_{28}$ VEGFR-1 intracellular isoform of 85 aa. Circles denote extracellular immunoglobulin domains not present in the intracellular variants; orange rectangles show the split kinase domain, or slightly trimmed kinase in $i_{19}$ VEGFR-1. 
VEGFR-1 PROTEINS and PUTATIVE INTRACELLULAR ISOFORMS

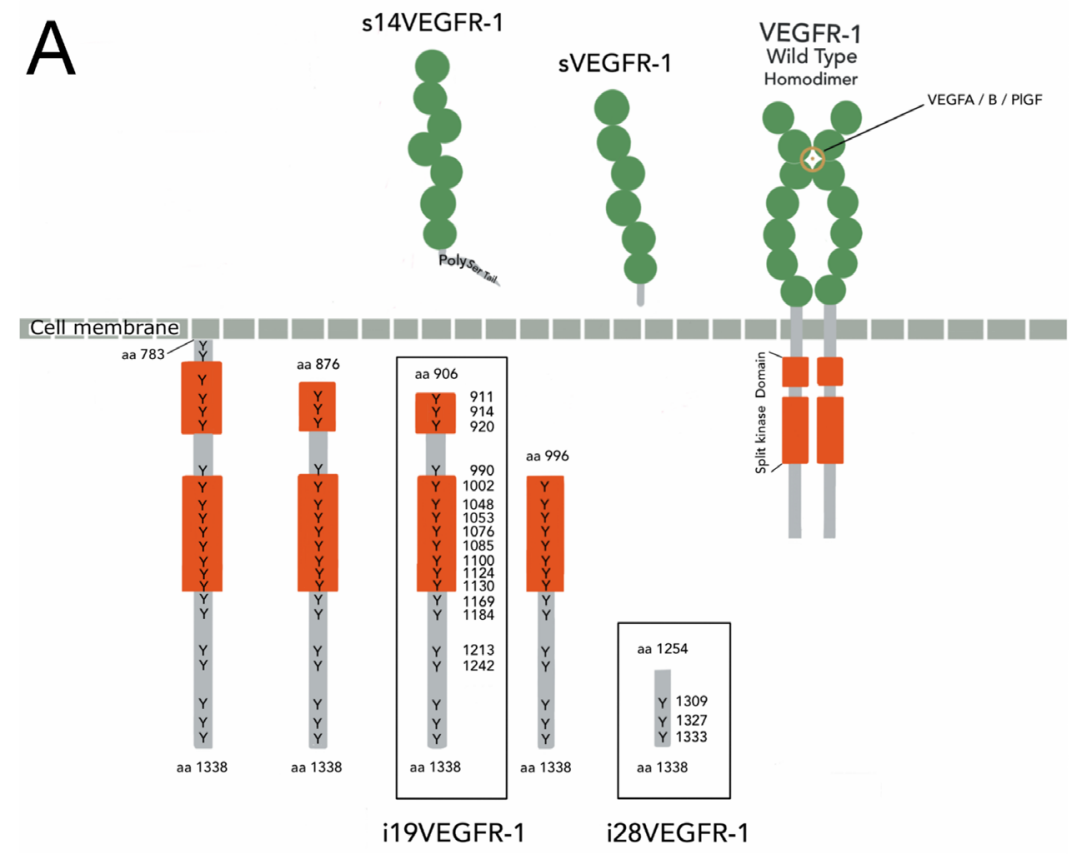

B

\begin{tabular}{|c|c|c|c|c|}
\hline Isoform name & Location & Context discovery & Function & $\begin{array}{c}\text { GenBank } \\
\text { Acc.no }\end{array}$ \\
\hline $\begin{array}{l}\text { Full-length VEGFR-1 } \\
\text { Wild type (also FLT1) }\end{array}$ & Membrane & $\begin{array}{l}\text { Endothelial cells } \\
\text { (EC). Also reported } \\
\text { in non-EC }\end{array}$ & $\begin{array}{l}\text { Angiogenesis, } \\
\text { Vasculogenesis and cell } \\
\text { migration }\end{array}$ & $\begin{array}{l}\text { NT_024524 } \\
\text { NM_002019 }\end{array}$ \\
\hline sVEGFR-1 & $\begin{array}{l}\text { Secreted } \\
\text { extracellular }\end{array}$ & Endothelial cells & $\begin{array}{c}\text { VEGF and PIGF ligand } \\
\text { high-affinity trap }\end{array}$ & U01134 \\
\hline s14VEGFR-1 & $\begin{array}{l}\text { Secreted } \\
\text { extracellular }\end{array}$ & $\begin{array}{l}\text { Endothelial and } \\
\text { Trophoblast cells }\end{array}$ & $\begin{array}{l}\text { Potentially same as } \\
\text { sVEGFR-1. Serine tail of } \\
\text { unknown function }\end{array}$ & EU36060600 \\
\hline ¡15VEGFR-1 & $\begin{array}{l}\text { Intracellular, very } \\
\text { low amounts }\end{array}$ & $\begin{array}{l}\text { MDA-MB-231 } \\
\text { cancer cells }\end{array}$ & Unknown & $\begin{array}{l}\text { DQ836394 } \\
\text { and } \\
\text { DQ836395 }\end{array}$ \\
\hline i18VEGFR-1 & $\begin{array}{l}\text { Intracellular, very } \\
\text { low amounts }\end{array}$ & $\begin{array}{l}\text { MDA-MB-231 } \\
\text { cancer cells }\end{array}$ & Unknown & EF491868 \\
\hline i21VEGFR-1 & Intracellular & $\begin{array}{l}\text { MDA-MB-231 } \\
\text { cancer cells }\end{array}$ & $\begin{array}{l}\text { SRC Kinase trans- } \\
\text { phosphorylation }\end{array}$ & $\begin{array}{l}\text { EF491869 } \\
\text { and } \\
\text { EF491870 }\end{array}$ \\
\hline i19VEGFR-1 & Intracellular & $\begin{array}{l}\text { Mature testis and } \\
\text { Spermatozoa } \\
\text { This work }\end{array}$ & $\begin{array}{l}\text { SRC Kinase binding and } \\
\text { trans-phosphorylation }\end{array}$ & JF509744 \\
\hline i28VEGFR-1 & Intracellular & $\begin{array}{l}\text { Mature testis and } \\
\text { Spermatozoa } \\
\text { This work }\end{array}$ & Unknown & JF509745 \\
\hline
\end{tabular}

Figure 2: (A) VEGFR-1 receptor proteins shown in their respective compartments, with the numbering of their tyrosine's residues, which are found at high density within the intracellular domain. Extracellular (named soluble) VEGFR-1 proteins contain the immunoglobulin domains (green circles) and end in specific tails. The full-length transmembrane VEGFR-1 receptor contains the immunoglobulin domains, the transmembrane and the juxta-membrane domains, as well as the intracellular split kinase domain ending in a C-terminal tail. Intracellular isoforms contain the whole kinase domain, part of it, or non-kinase domain ( $\mathrm{i}_{28}$ VEGFR-1). (B) Box detailing distinctive characteristics for the different VEGFR-1 isoforms. 
Table 1: Primers, with indication of gene sequence, size, polarity and specificity

\begin{tabular}{|c|c|c|c|}
\hline Primer & Sequence & Size & Polarity/position in full-length VEGFR-1 \\
\hline HFE11U & 5'CATCACTCAGCGCATGGCAAT3' & $21 \mathrm{mer}$ & Forward/exon 11 \\
\hline HFE12U & 5'AGCACCTTGGTTGTGGCTGAC3' & 21 mer & Forward/exon 12 \\
\hline HFs13D & 5'TTGTTGCAGTGCTCACCTCTGA3' & 22 mer & $\begin{array}{l}\text { Reverse/intron } 13 \text { sVEGFR-1 specific/splints exon and } \\
\text { intron } 13 .\end{array}$ \\
\hline $\begin{array}{l}\text { HFE11U- } \\
\text { HFs13D }\end{array}$ & & $474 \mathrm{bp}$ & $\begin{array}{l}\text { Detects sVEGFR-1. Skips intron } 11 \text { and exon and intron } \\
12 .\end{array}$ \\
\hline $\begin{array}{l}\text { HFE12U- } \\
\text { HFs13D }\end{array}$ & & 428 bp & $\begin{array}{l}\text { Detects selectively sVEGFR-1 isoform. } \\
\text { Skips intron } 12 .\end{array}$ \\
\hline HFE14U & 5'GATCAGGAAGCACCATACCTCCTG3' & 24 mer & Forward/exon 14 \\
\hline HFs14D & 5'GGTGATGATGACGATGACGATGG3' & 23 mer & Reverse/intron 14, $\mathrm{s}_{14}$ VEGFR-1 specific. \\
\hline $\begin{array}{l}\text { HFE14U- } \\
\text { HFs14D }\end{array}$ & & $191 \mathrm{bp}$ & Detects selectively $\mathrm{s}_{14}$ VEGFR-1 isoform. Skips intron 14 \\
\hline HFe14U & 5'TCCCCGAGCCTCAGATCACTTG3' & 22 mer & Forward/exon 14 \\
\hline Flt1Fw & 5'GATGTTGAGGAAGAGGAGGATT3' & 22 mer & Forward/splints exons 21 and 22. \\
\hline Flt1Rv & 5'AAGCTAGTTTCCTGGGGGTATA3' & 22 mer & Reverse/exon 30, 3'UTR \\
\hline $\begin{array}{l}\text { Flt1Fw- } \\
\text { Flt1Rv }\end{array}$ & & $1,146 \mathrm{bp}$ & Probe synthesis \\
\hline HFE15D & 5'CTGGTTGGTGGCTTTGCAGTG3' & $21 \mathrm{mer}$ & Reverse/exon 15 \\
\hline $\begin{array}{l}\text { HFE14U- } \\
\text { HFE15D }\end{array}$ & & $241 \mathrm{bp}$ & $\begin{array}{l}\text { Detects full-length VEGFR-1 as well as isoforms with } \\
\text { membrane and juxta-membrane domains. }\end{array}$ \\
\hline HFI19U & 5'CCCAGGCATGCAGTGGAAAC3' & 20 mer & Forward/intron $19, \mathrm{i}_{19}$ VEGFR-1 specific \\
\hline HF20D & 5'CGTTTGCTCTTGAGGTAGTTGGAG3' & 24 mer & Reverse/exon 20 \\
\hline $\begin{array}{l}\text { HFI19U- } \\
\text { HF20D }\end{array}$ & & 190 bp & $\begin{array}{l}\text { Detects selectively } i_{19} \text { VEGFR-1. Skips a large fragment } \\
\text { of intron } 19 .\end{array}$ \\
\hline HFE22D & 5'GACAGGAACTCCATGCCTCTGG3' & 22 mer & Reverse/exon 22 \\
\hline $\begin{array}{l}\text { HFI19U- } \\
\text { HF22D }\end{array}$ & & $457 \mathrm{bp}$ & $\begin{array}{l}\text { Detects selectively } i_{19} \text { VEGFR-1. Skips a large fragment } \\
\text { of intron } 19 \text { plus exons and introns } 20 \text { and } 21 .\end{array}$ \\
\hline HFI28U & 5'CAGCTGTGTTCCTACCCAATCAC3' & 23 mer & Forward/intron $28, \mathrm{i}_{28}$ VEGFR-1 specific \\
\hline HFE30D & 5'TCAGACAGCCCCGACTCCTTAC3' & 22 mer & Reverse/exon 30 \\
\hline $\begin{array}{l}\text { HFI28U- } \\
\text { HFE30D }\end{array}$ & & $197 \mathrm{bp}$ & Detects selectively $i_{28}$ VEGFR-1. Skips exon intron 29. \\
\hline HFE29U & 5'GACTACCAGGGCGACAGCAGC3' & 21 mer & Forward/exon 29 \\
\hline HFE30D & 5'TCAGACAGCCCCGACTCCTTAC3' & 22 mer & Reverse/exon 30 \\
\hline $\begin{array}{l}\text { HFE29U- } \\
\text { HFE30D }\end{array}$ & & $137 \mathrm{bp}$ & $\begin{array}{l}\text { Amplifies all variants isoforms containing the C-terminal } \\
\text { tail. }\end{array}$ \\
\hline HCID & 5'CAGCTGGAATGGCAGAAACTGG3' & 22 mer & Reverse/exon 30 \\
\hline $\begin{array}{l}\text { HFE29U- } \\
\text { HCID }\end{array}$ & & $170 \mathrm{bp}$ & $\begin{array}{l}\text { Amplifies all variants isoforms containing the C-terminal } \\
\text { tail. }\end{array}$ \\
\hline HFrev2 & 5'GGCAAAAGCTAGTTTCCTGGGGGTATA3' & 27 mer & Reverse/exon 30, 3'UTR. \\
\hline 19EAT & 5'ATACAGAATTCGATGGTGATTGTTGAAT3' & 28 mer & $\mathrm{i}_{19}$ VEGFR-1 cloning \\
\hline HFFP & $\begin{array}{l}\text { 5'GTCGTCATCCTTGTAATCGATGGGTGGG } \\
\text { GTGGAG3' }\end{array}$ & 34 mer & $\mathrm{i}_{19}$ VEGFR-1 cloning plus partial flag tagging. \\
\hline HFFFA & $\begin{array}{l}\text { 5'CAAGAGGGCCCTCACTTATCGTC } \\
\text { GTCATCCTTGTA3' }\end{array}$ & 35 mer & $\mathrm{i}_{19}$ VEGFR-1 cloning and complete flag tagging. \\
\hline HAF & 5'CCTCGCCTTTGCCGATCC3' & 18 mer & Forward/endogenous $\beta$-Actin \\
\hline HAR 180 & 5'ATCACGCCCTGGTGCCTG3' & 18 mer & Reverse/endogenous $\beta$-Actin \\
\hline $\begin{array}{l}\text { HAF- } \\
\text { HAR180 }\end{array}$ & & $180 \mathrm{bp}$ & $\beta$-Actin. Skips intron. \\
\hline
\end{tabular}


part of the blot correspond to a disturbing unspecific artifact present in both, competed and non-competed lines.

\section{Protein kinase receptor $i_{19}$ VEGFR-1 binds and activates Src-protein kinases}

We have previously reported that $i_{21}$ VEGFR-1 in MDA-MB-231 breast cancer cells was able to enhance phosphorylation of Src [20]. Because the $i_{19}$ VEGFR-1 is slightly larger and contains all the $i_{21}$ VEGFR-1 domains, we reasoned that it too would enhance Src phosphorylation. Co-transfection of CHO cells or HEK293 cells with recombinant plasmids containing the coding sequences for $i_{19}$ VEGFR-1 and Src, produced a remarkable phosphorylation of tyrosine $\mathrm{Y}^{418}$, and so activation of SRC (Figure 6A). The increase in $\mathrm{Y}^{418}$ phosphorylation is much more lower when Src is transfected without $i_{19}$ VEGFR-1.

Moreover, after over-expressing Flag tagged$\mathrm{i}_{19}$ VEGFR-1 with Src (or Fyn) kinase by cell cotransfection we detected more Src (or Fyn) protein bound to the anti-flag resin beads when Flag tagged-i ${ }_{19}$ VEGFR-1 protein was present (Figure 6B), suggesting binding of $\mathrm{i}_{19}$ VEGFR-1 to Src and Fyn kinases.

\section{Sequence elements that may induce $i_{19}$ VEGFR-1 and $i_{28}$ VEGFR-1 transcription}

The two isoforms, $i_{19}$ VEGFR-1 and $i_{28}$ VEGFR-1, originate at an alternative transcriptional start site (aTSS) in introns 19 and 28, respectively, of the full-length VEGFR-1 receptor.

We took advantage of the huge amount of available information (Encode/Jaspar/Consite) and searched in silico for potential DNA binding elements and chromatin cues that allowed $i_{19}$ VEGFR-1 and $i_{28}$ VEGFR-1 transcription in testis (Figure 7). The sequence RGGTCA, to which CREM factors, nuclear factors and $\mathrm{ROR} \alpha$ transcription factors can bind, was over-represented relatively to RCGTCA, the canonical half-CRE site [23]. A putative p53 responsive element [22] (marked in red in Figure 7A), with

\section{NORTHERN BLOT TOTAL RNA}

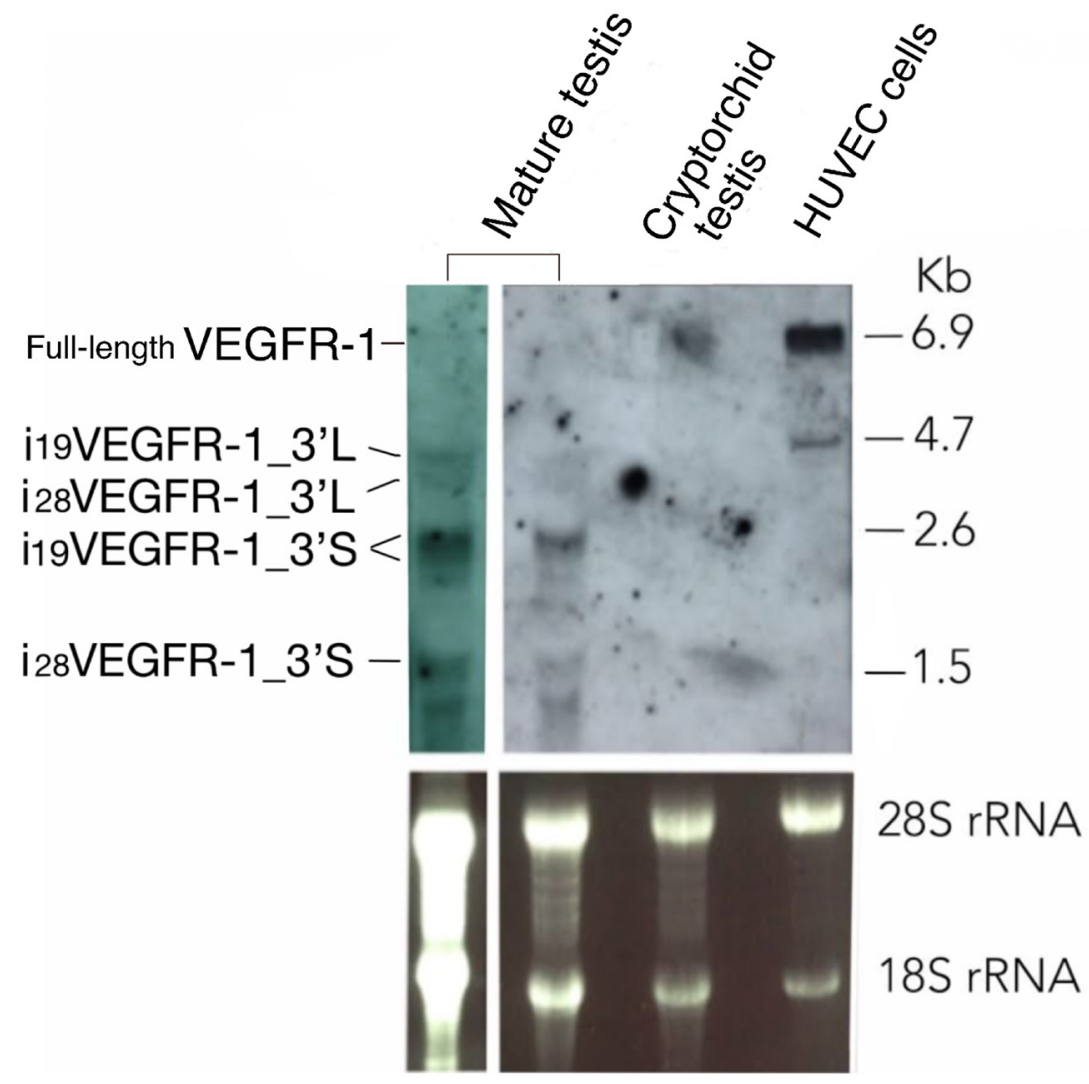

Figure 3: Northern blot pattern of VEGFR-1 from total RNA expressed in mature testis, cryptorchid testis and HUVEC cells as indicated. Agarose-formaldehyde gel blotted and hybridized using a probe complementary to the kinase domain. RNA loads correspond to $40 \mu \mathrm{g}$ (left lane) or $20 \mu \mathrm{g}$ (all other lanes) of total RNA. 3'L and 3'S denote $\mathrm{i}_{19}$ VEGFR-1 and $\mathrm{i}_{28}$ VEGFR-1 transcripts, displaying either, whole length or shorter (675 nt) 3'UTR, respectively. Bottom panel: Ribosomal staining as a visual indicator of sample loading. 
A MATURE TESTIS RT-PCR

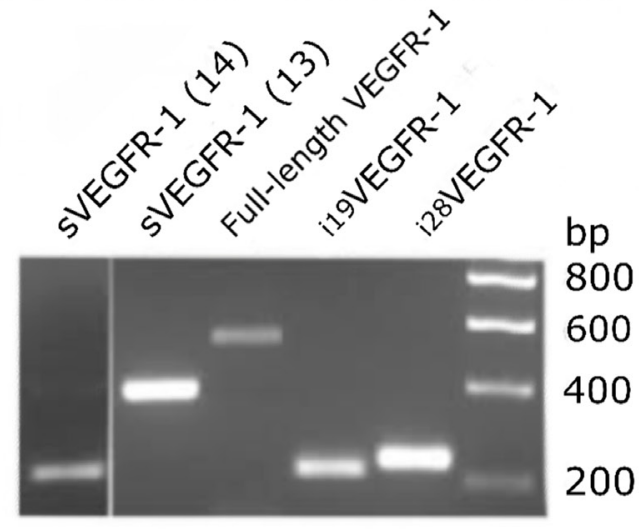

C SPERM RT-PCR

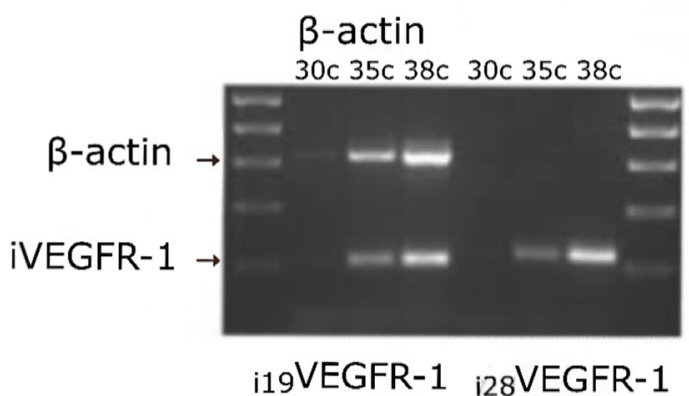

i19VEGFR-1 i28VEGFR-1
B

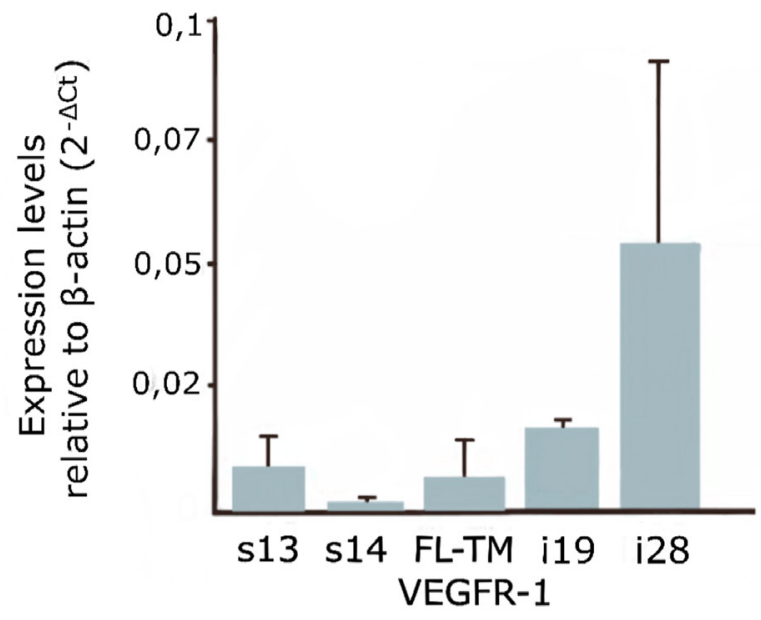

$\mathrm{D}$
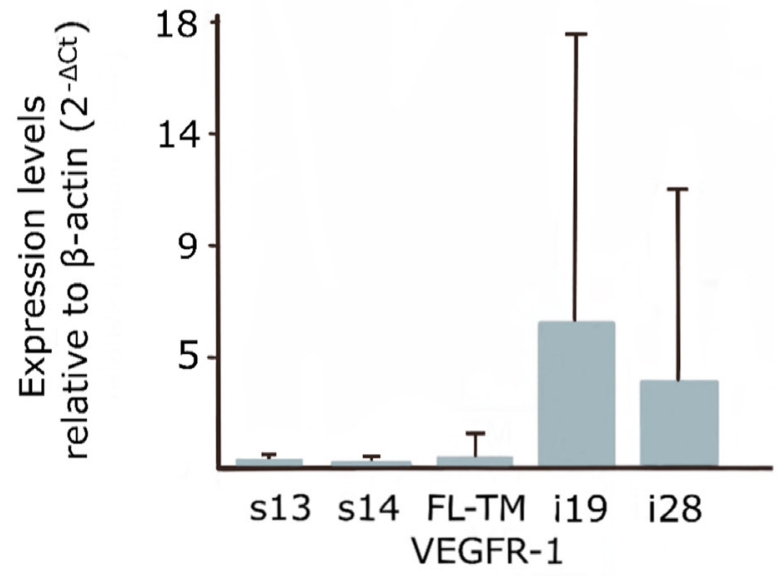

$\mathrm{F}$
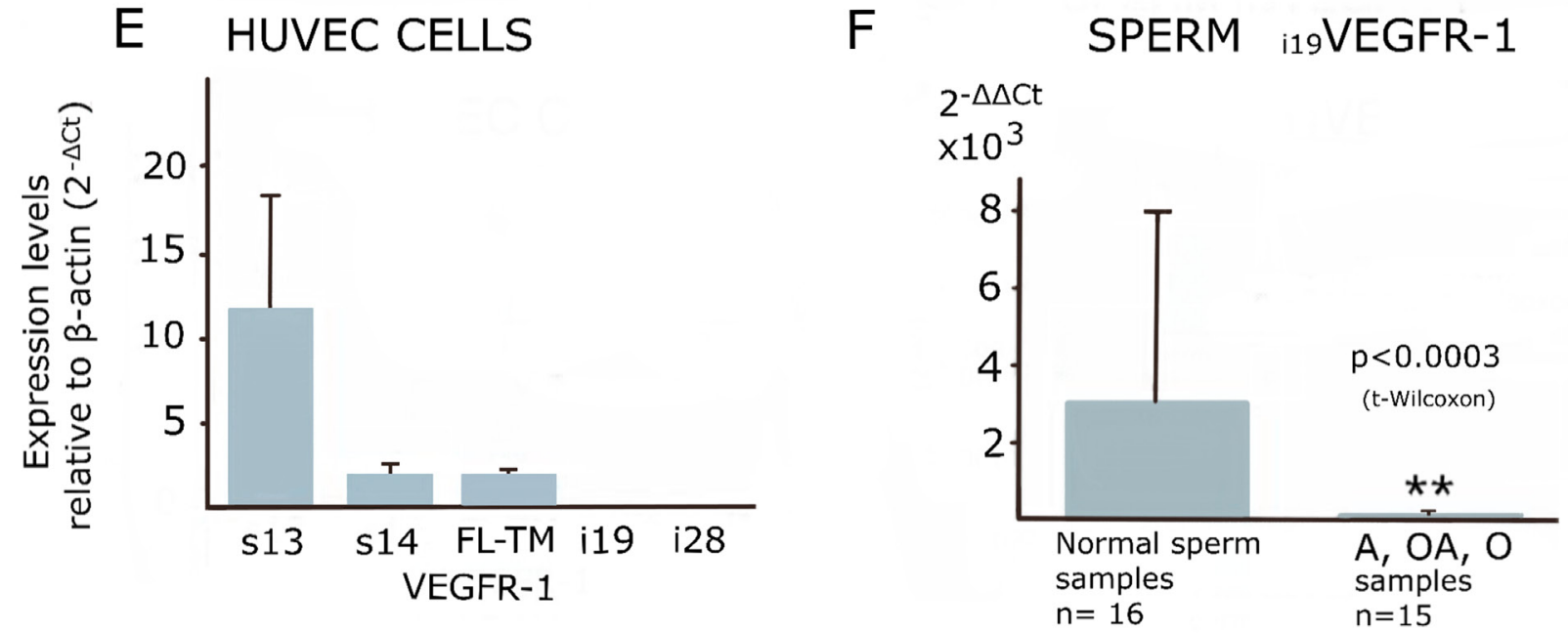

Figure 4: Expression of VEGFR-1 variants analyzed by manual, semi-quantitative and real-time PCR. (A and C) Ethidium bromide image of a 1.5\% agarose gel. (B, D and E) Real time-PCR quantification relative to $\beta$-actin, showing standard deviation. (F) Statistical Bar Graph showing relative expression values of $i_{19}$ VEGFR-1 in spermatozoa, relative to $\beta$-actin and referred to $i_{19}$ VEGFR- 1 levels in mature testis $\left(2^{-\Delta \Delta \mathrm{C} t}\right)$. The pool of sperm defective samples (see methods), $n=15$ shows a significantly decreased $\left({ }^{* *} p<0.0003\right)$ in $\mathrm{i}_{19}$ VEGFR-1 expression when compared with the pool of non-defective spermatozoa $(n=16$, normal) by the same parameters. VEGFR-1, full-length (FL) transmembrane (TM) receptor, sVEGFR-1 (s13), s14VEGFR-1 (s14). 
Table 2: Antibodies used

\begin{tabular}{|c|c|c|c|c|c|}
\hline $\begin{array}{c}\text { Primary } \\
\text { Antibodies }\end{array}$ & $\begin{array}{c}\text { Host } \\
\text { species }\end{array}$ & $\begin{array}{l}\text { Reactivity/cross- } \\
\text { reactivity }\end{array}$ & Dilution & Company & Clonality \\
\hline $\begin{array}{l}\text { Anti-VEGFR-1 } \\
\text { \#2893 }\end{array}$ & Rabbit & $\begin{array}{l}\text { Human/do not cross- } \\
\text { react with VEGFR-2 } \\
\text { or VEGFR-3, neither } \\
\quad \text { with sVEGFR-1 }\end{array}$ & $1: 1000$ & Cell Signaling & $\begin{array}{l}\text { Polyclonal against } \\
\text { residues surrounding } \\
\text { Thr } 1307\end{array}$ \\
\hline Src \#2108 & Rabbit & $\begin{array}{l}\text { Human and other } \\
\text { species }\end{array}$ & $1: 1000$ & Cell Signaling & $\begin{array}{l}\text { Polyclonal against } \\
\text { residues close to the } \\
\text { carboxylate terminus of } \\
\text { human Src }\end{array}$ \\
\hline $\begin{array}{c}\text { Phospho-Src } \\
\text { (Tyr 418) } \\
\text { \# 44-660G, RRID } \\
\text { AB_2533714 }\end{array}$ & Rabbit & $\begin{array}{l}\text { Human and other } \\
\text { species }\end{array}$ & $1: 1000$ & $\begin{array}{l}\text { Invitrogen/ } \\
\text { ThermoFisher Scientific }\end{array}$ & Polyclonal against $\mathrm{P}^{\mathrm{Y} 418}$ \\
\hline $\begin{array}{l}\text { Flt-1 C-17 } \\
\text { \#Sc-316 }\end{array}$ & Rabbit & $\begin{array}{l}\text { Human and other } \\
\text { species }\end{array}$ & $1: 200$ & $\begin{array}{c}\text { Santa Cruz } \\
\text { Biotechnology }\end{array}$ & $\begin{array}{l}\text { Polyclonal against } \\
\text { C-terminus }\end{array}$ \\
\hline $\begin{array}{l}\text { Fyn3 } \\
\text { \#sc16 }\end{array}$ & Rabbit & $\begin{array}{l}\text { Human and other } \\
\text { species }\end{array}$ & $1: 300$ & $\begin{array}{c}\text { Santa Cruz } \\
\text { Biotechnology }\end{array}$ & Polyclonal \\
\hline $\begin{array}{l}\text { Anti- } \beta \text { Actin } \\
\text { \#A5316 }\end{array}$ & Mouse & $\begin{array}{l}\text { Human and other } \\
\text { species }\end{array}$ & $1: 5000$ & Sigma & Monoclonal \\
\hline $\begin{array}{c}\text { Anti } \alpha \text {-Tubulin } \\
\text { \#T6074 }\end{array}$ & Mouse & $\begin{array}{l}\text { Human and other } \\
\text { species }\end{array}$ & $2 \mathrm{ng} / \mathrm{mL}$ & Sigma & $\begin{array}{c}\text { Monoclonal } \\
\text { epitope at C-terminal }\end{array}$ \\
\hline
\end{tabular}

a 9 nucleotides stalk and 7 nucleotides loop is located just after the TSS of the $i_{19}$ VEGFR-1 gene, and is preceded (23 nucleotides before) by another palindrome with the stalk of the RGGTCA sequence just mentioned (Figure 7A).

The transcription start sites, Hot Spots for transcription activation, $\mathrm{CpG}$ islands, DNase hypersensitive peak clusters, and Histone H3 Lys27 acetylation (H3K27ac) marks around the aTSS of $i_{19}$ VEGFR-1 and $\mathrm{i}_{28}$ VEGFR-1 are shown in Figure 7. Worth mentioning, are binding sites for Sox 17 and Sox5, pioneering transcription factors involved in post-meiotic remodeling and over-represented near the aTSS of the $i_{19}$ VEGFR-1 and $\mathrm{i}_{28}$ VEGFR-1. Also the Spzl transcription factor, located in both $i_{19}$ VEGFR-1 and $i_{28}$ VEGFR-1 promoter regions, that functions as a spermatogenic Zip Protein relevant for spermatogenesis.

\section{DISCUSSION}

Two transcript variants, $\mathrm{i}_{19}$ VEGFR-1 and $\mathrm{i}_{28}$ VEGFR-1, of the VEGFR-1 receptor, missing the extracellular and transmembrane domains and therefore intracellular and independent of ligands, are predominantly expressed, over the complete transmembrane transcript and soluble variants of the VEGFR-1 gene, in mature testis and human sperm cells. The two isoforms start TATA-less transcription in introns 19 and 28, respectively, in rich polypyrimidine stretches, a characteristic shared by transcripts without a TATA-box [24] and incorporate leader sequences from the respective introns were transcription starts. The palindromic p53 element [22] in the $\mathrm{i}_{19}$ VEGFR-1 transcripts (nucleotides 2 to 22) may confer regulatory potential after transcription. The presence in the $i_{19}$ VEGFR-1 transcript of out-of-frame uORFs in the 5'UTR (Figure 1), may also modulate translation and stabilize the transcripts $[25,26]$.

We have previously observed that several genes selectively expressed during spermatogenesis use alternative transcription start sites and alternative splicing, giving raise to differential $5^{\prime}$ and $3^{\prime}$ regions. Also shorter 3'UTRs, by eliminating destabilizing sequences, give rise to more stable transcripts $[3,4]$. In the case of $\mathrm{i}_{19}$ VEGFR-1 and $\mathrm{i}_{28}$ VEGFR-1 isoforms, shorter 3'UTRs are predominantly expressed (Figure 2). Shortening of the 3'UTR in VEGFR-1, eliminates a distal GT-repeat sequence of the VEGFR-1 receptor that is considered a determinant of allele instability [27].

Cryptorchid testis, having just spermatogonia germ cells and lacking differentiated spermatogenic cells, do not express $i_{19}$ VEGFR-1 and $i_{28}$ VEGFR-1 isoforms. In addition, both isoforms are enriched in spermatozoa relatively to mature testis.

We found a statistically significant $(p<0.0003)$ higher expression of $i_{19}$ VEGFR-1 mRNA in the spermatozoa of men with normal semen parameters [21] compared to asteno, oligo or oligoastenozoospermic patients, suggestive of a role for $\mathrm{i}_{19}$ VEGFR-1 in male fertility; however, we are cautious and larger clinical studies are to be done to confirm these data. 
The $\mathrm{i}_{19}$ VEGFR-1 transcripts translate to a protein of $49 \mathrm{kD}$ (Figure 5). The $\mathrm{i}_{19}$ VEGFR-1 protein is a little bigger, but similar in domains' conservation to the isoform expressed in cancer cells [20]. Both truncated kinases activate the Src protein kinase and are very similar to Tr-KIT, a truncated variant of the c-KIT protein kinase, essential for sperm DNA integrity and proposed as a marker of human sperm quality [28], also important for activation of the parthenogenesis [29]. The $i_{19}$ VEGFR-1 kinase matches the Tr-KIT as it also conserves the phosphotranspherase-domain and the carboxy-terminal tail of the full-length protein. Without the ATP binding site, it lacks autophosphorylation ability. Anyway, $i_{19}$ VEGFR-1 induces a robust phosphorylation and activation of the Src kinases, as we have demonstrated through cotransfection of cells with both recombinant constructs (Figure 6).

Haploid expression depends on short stretches located close to the aTSS [30, 31], and truncation and the utilization of cryptic intragenic promoters has been proposed as a transcriptional signature of the germ cells undergoing terminal differentiation [5, 30]. This frequently involves the use of transcription factors like
CREM $\tau$ (cAMP response element modulator tau) and GCNF (germ cell nuclear factor). These factors use an overlapping DNA binding site that is sufficient to direct cell type-specific expression in vivo $[23,32]$. The same binding element is used by the transcription factor ROR $\alpha$ [33] and is present several times in both $i_{19}$ VEGFR-1 and $\mathrm{i}_{28}$ VEGFR-1 regulatory region (Figure 7). A palindromic p53 conserved DNA binding element in $\mathrm{i}_{19}$ VEGFR- 1 is not only found in the gene, it is also incorporated within the first 23 nucleotides (from 2 to 22) of the transcript and may form a hairpin structure (Figure 7A). Manual and in silico analysis of the regions around $i_{19}$ VEGFR- 1 and $\mathrm{i}_{28}$ VEGFR-1 aTSS, demonstrated an extensive repertoire of DNA binding sites, hot-spots, high density CpG Island, DNase hypersensitive peak clusters, and protein marks in both genes (Figure 7). These DNA regions may allow for chromatin opening and expression of the mRNA in testis cells. Worth mentioning are the presence of specific DNA binding sequence elements in the proximal promoters of these isoforms, like Sox17, Sox5 or Spz1 binding sites (Figure 7). Sox 5 has been found within the nucleus of mouse post-meiotic round spermatids [34]. Sox17 is

\section{WESTERN BLOT}

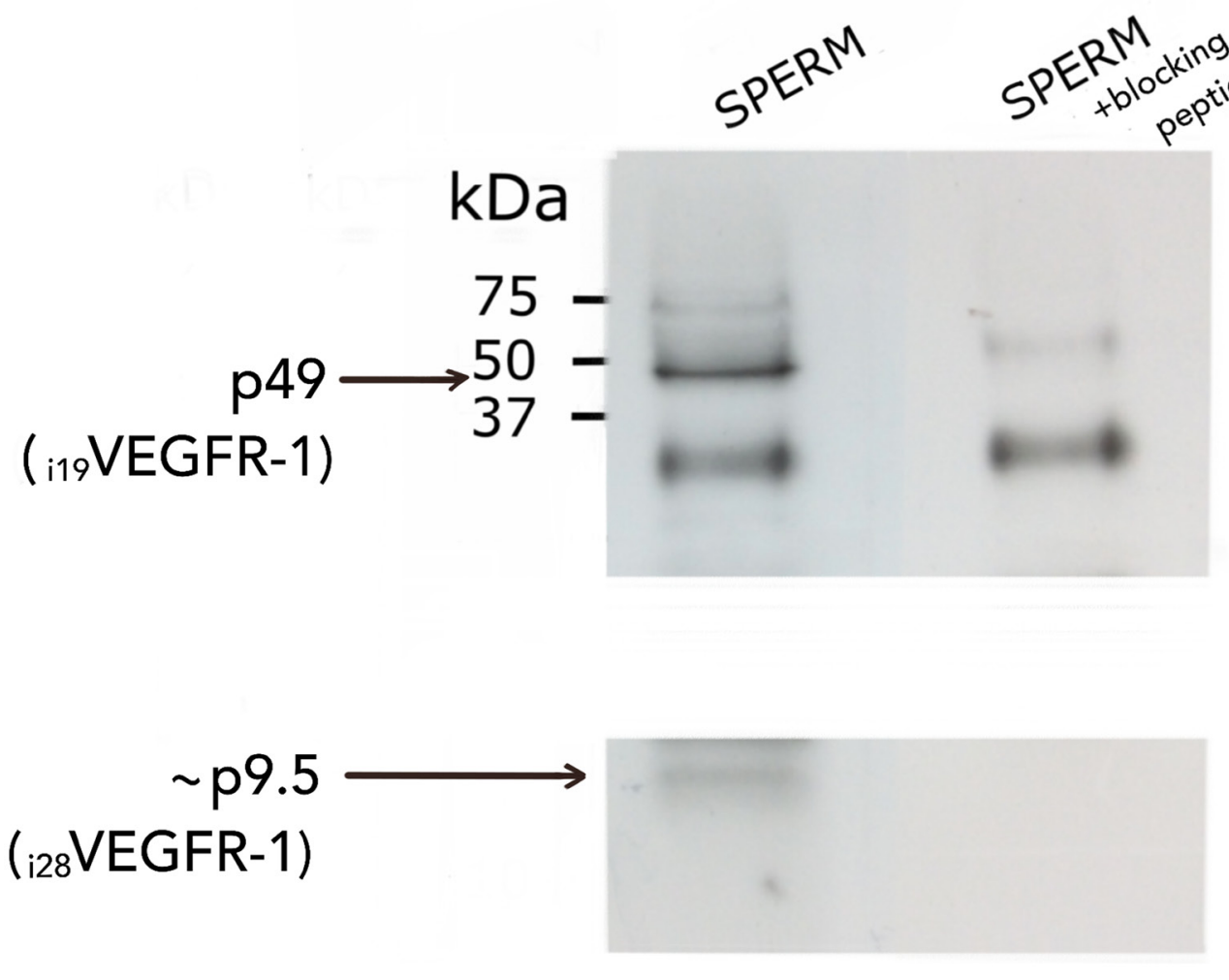

Figure 5: Western blot analysis of $i_{19}$ VEGFR-1 (p49) (49kDa) and putative $i_{28}$ VEGFR-1 (p9.5) (9.5kDa) isoforms expressed in normal sperm samples. Detection was carried out with the anti-VEGFR-1 antibody sc-316 from Santa Cruz, and validated by competition with a specific peptide (see methods). At left, molecular weight markers BioRad. The cropped part of the blot correspond to a disturbing unspecific artifact present in both, competed and non-competed lines. 
detected in about $10 \%$ of all testis specific genes [35], and Spz1, a spermatogenic Zip regulatory Protein [36], is drastically reduced in meiotic cells of oligozoospermic infertile men [37].

Given the conserved prevalence of truncated isoforms, preferentially truncated tyrosine kinases [5], within the spermiogenic transcriptome, truncated receptor kinases $i_{19}$ VEGFR- 1 and $i_{28}$ VEGFR-1 may play a relevant role in and after the post-meiotic stages of spermatogenesis. From the drastic remodeling processes that the cells undergo to become spermatozoa until the sequential remodeling of the plasmatic membrane that occur during activation and capacitation. Important players in these processes are different truncated kinases [5] as well as the SRC-family kinases (SFK) [38], that are activated by selective tyrosine phosphorylation. In this processes, $\mathrm{i}_{19}$ VEGFR-1 may be either absolutely required or play an important redundant role. Worth mentioning is the parallelism that exist between $\mathrm{i}_{19}$ VEGFR-1 and TrKIT-receptor tyrosine kinases. Both belong to the same subclass (Subclass III) of receptor tyrosine kinases [39], activate SKFs, and exist in spermatozoa as truncated variants of the full transmembrane receptor [28]. Although the VEGFR-1 homozygous mice defective for the tyrosine kinase domain reaches the second generation [40], we believe that the lack of these isoform is a risky situation for the correct process of fertilization.
Potential mechanisms to explain why the expression of the $i_{19}$ VEGF isoform may be repressed in infertile semen samples, may be found at the genome level or at the stability of the mRNA. At the genome level, either, mutations in the enhancers or promoters of pioneers or other specific transcription factors, may affect negatively the expression program that develops during differentiation of spermatogenic cells, decreasing the levels of truncated isoforms like $i_{19}$ VEGF. In addition, mutations in the coding regions of the same factors, implied in TSS selection and splicing may affect their ability to produce these alternate isoforms.

In conclusion, the two $\mathrm{i}_{19}$ VEGFR-1 and $\mathrm{i}_{28}$ VEGFR-1 isoforms, by taking advantage of the intron-exon architecture of the VEGFR-1 gene and the opening of intronic platforms for transcription, are the predominant VEGFR-1 isoforms expressed in spermatogenic cells. They can be expressed as proteins without any dependence on ligands, and in the case of $i_{19}$ VEGFR-1, it manifests a strong ability to phosphorylate and activate Src kinases, critical for sperm capacitation and fertility. Altogether, $i_{19}$ VEGFR-1, either critical or redundant to other truncated kinases like Tr-KIT, may be an important device for sperm remodeling, capacitation and fertilization. Further clinical studies are needed to extend the significance of these VEGFR-1 isoforms as markers of human infertility.

\section{WESTERN BLOT}
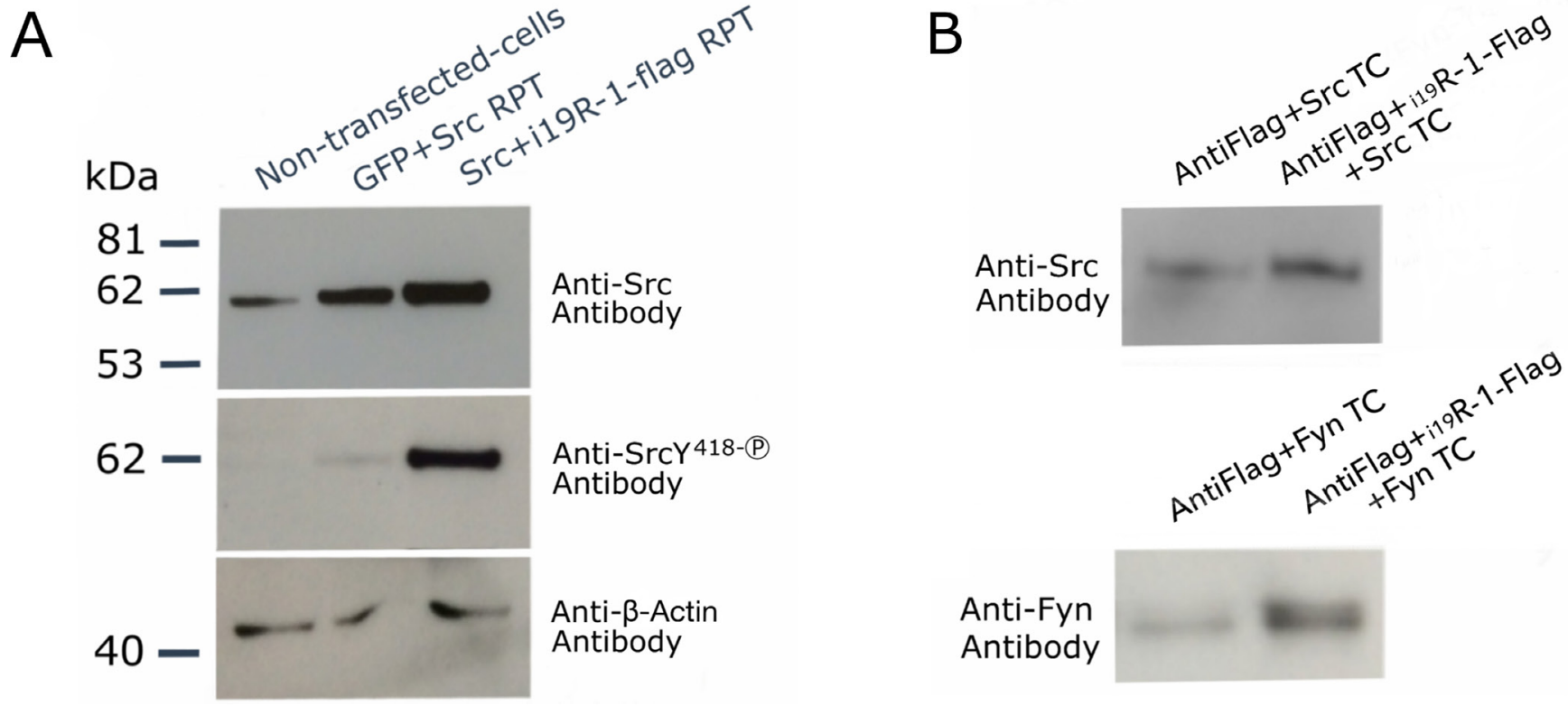

Figure 6: Western blot analysis showing transphosphorylating activity and binding of $i_{19}$ VEGFR-1 on Src kinases. (A) Cells (CHO-cells) were either, non-transfected, transfected (TC) with recombinant GFP plus Src recombinant plasmid (RPT), or transfected with Src recombinant plasmid (RP plus flag-tagged $i_{19}$ VEGFR-1 RP). The detecting antibodies, anti-Src, Anti-SrcY418-P (phosphorylated activating Y residue) and anti- $\beta$-Actin, are shown at right. The $\beta$-actin was used as the loading control. (B) Binding experiments to assess physical interaction between $i_{19}$ VEGFR-1 and SRC (FYN) kinases. Either, protein extracts over-expressing only active SRC or FYN kinases (TC, Transfected cells) or one of this kinases plus $i_{19}$ VEGFR-1 tagged to flag, were assayed for binding to and Anti-flag gel as described (see methods). Detecting antibodies are shown at left. 


\section{${ }_{i 19}$ VEGFR-1 and ${ }_{\text {i28 }}$ VEGFR-1 GEN PROMOTER}

A
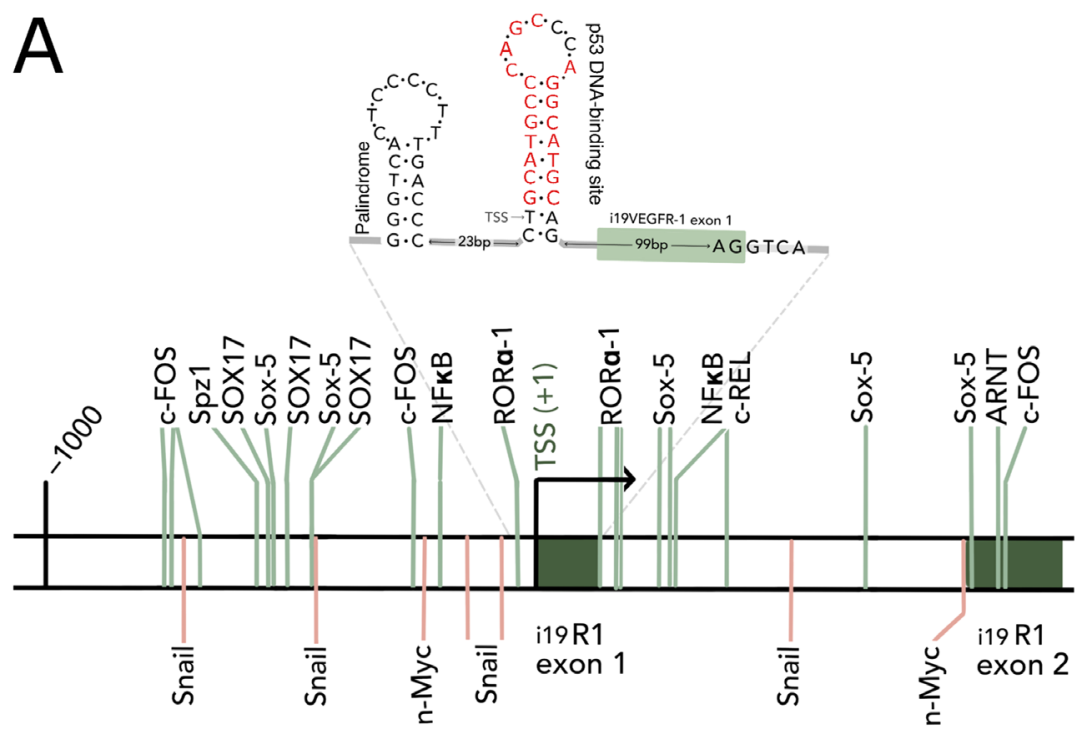

\begin{tabular}{l}
\hline DNAse I hypersensitivity / Hot spot $\rightarrow$ \\
\hline CpG islands $\rightarrow$ \\
\hline H3K27ac \\
\hline
\end{tabular}

B

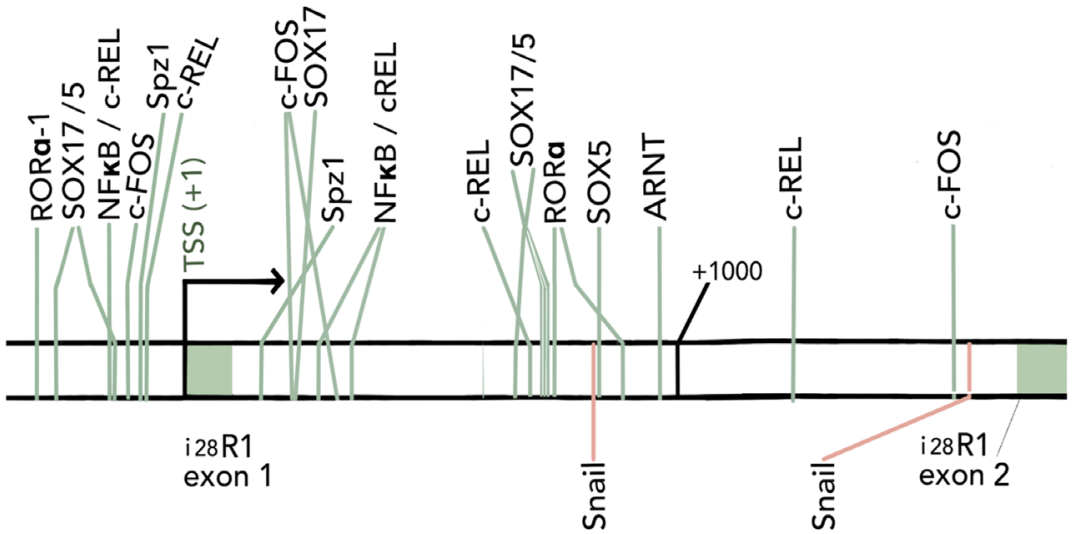

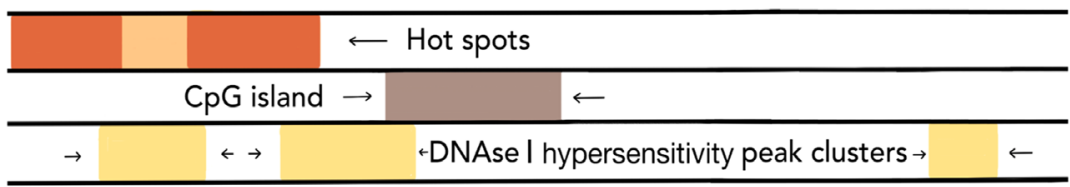

Figure 7: (A) In silico reported elements around the TSS (arrow) of $\mathrm{i}_{19}$ VEGFR-1 gene. Two palindromic sequences, spaced by 23 nucleotides, first one with the stalk of the RGGTCA sequence (see results) and the second one with a p53 responsive element (RE) [22] (in red), are depicted at the top of the Figure. The p53 palindrome is just placed at the transcription start site (TSS) of $i_{19}$ VEGFR-1. Vertical lines depict DNA response elements, located in the proximal promoter and first intron. DNase I hypersensitivity hot spots (rectangles in first intron), $\mathrm{CpG}$ islands (rectangles in proximal promoter and first intron) and H3K27ac marks (waves decreasing in height towards the first $i_{19}$ VEGFR-1 intron) are highlighted in color. (B) In silico reported elements around the TSS (arrow) of $i_{28}$ VEGFR-1 gene. Vertical lines depict DNA response elements located in the proximal promoter and first intron. Location of hot spots (consecutive rectangles around the TSS), CpG island (rectangle in the first intron), and DNase I hypersensitivity peak clusters (rectangles around the TSS and at the end of the $\mathrm{i}_{28}$ VEGFR-1 first intron) are highlighted in color. 


\section{MATERIALS AND METHODS}

\section{Semen samples and cryptorchidic testis}

Samples were obtained after informed consent, from sperm donors and patients from the Andrology Unit of the Hospital Clinic of Barcelona, and classified as normozoospermic, astenozoospermic, oligozoospermic or oligoastenozoospermic according to WHO 2010 parameters [21]. A total of 31 samples were individually processed to obtain total RNA, then reverse transcribed and quantified by real-time PCR to analyze expression. A total of 15 samples where considered defective, in number or linear motility as just mentioned, and grouped for statistical analysis to be compared to a pool of 16 nondefective samples (named normal) (Figure 4) by the same parameters. The pool of defective samples comprised: 10 astenozoospermic (A), 2 oligozoospermic (O) and 3 oligoastenozoospermic (OA) samples.

Semen was processed as described by De Mateo et al., 2007 [41]. Cell count was carried out with a Neubauer chamber.

Cryptorchidic testis was obtained from a patient undergoing surgical preventive intervention. The histological study of this cryptorchidic testis indicated complete absence of differentiated spermatogenic cells with presence of only somatic cells and spermatogonia.

\section{RNA/cDNA, electrophoresis, northern hybridization, and probes}

Human normal testis total RNA was obtained from Clontech (mixed population of men aged 1460). Two different batches were tested. The cDNA was prepared from this RNA, either, by reverse transcription (SuperScript III Reverse Transcriptase cat. no. 18080-093) or by One-Step RT-PCR (Qiagen cat. no. 210212).

Human total spermatozoa RNA (see Ethics statement) was prepared with the TriPure Isolation reagent (Roche), and/or RNeasy silica-membrane spin-columns (Qiagen) following the manufacturer instructions.

Cryptorchidic testis was immediately frozen and reduced to a homogenous powder (mortar) in liquid nitrogen. Total RNA was extracted with TriPure Isolation reagent, followed by further purification in RNeasy silicamembrane spin-columns (Qiagen), as before.

The procedure used for electrophoresis, northern blot, and preparation of DNA probes has been previously described [20].

Human VEGFR-1 kinase-domain primers (Table 1) were used to obtain a probe that hybridized with the fulllength VEGFR-1 mRNA and any VEGFR-1 containing the whole or part of the kinase domain and $\mathrm{C}$-tail.

\section{RACE5' and RACE3'}

The Human Testis Marathon-Ready cDNA (Clontech cat. no. 639314) for rapid amplification of cDNA ends (RACE), the primers included in the kit and specific ones for the specific isoforms (ThermoFisher Scientific, Table 1), as well as the conditions recommended by the manufacturer, were used.

\section{DNA sequencing}

Sequencing was conducted with the BigDye Terminator v3.1 (Applied Biosystems), as previously described, [20] and analyzed at the Autonomous University of Barcelona (CRAG Genomic Centre).

The nucleotide sequences of $\mathrm{i}_{19}$ VEGFR-1 and $\mathrm{i}_{28}$ VEGFR-1 isoforms were deposited in the GenBank database under accession numbers JF509744 and JF509745.

\section{Recombinant clones, cloning, electro- transformation, and DNA preparation}

Human Src recombinant clone was from OriGene Technologies and contained v-Src sarcoma transcript variant 1 (NM 005417) in pCMV6-XL4. Human Fynrecombinant clone was also from OriGene (NM_002037).

The $i_{19}$ VEGFR-1 coding region followed by the flag-tag were inserted into the pcDNA3.1(+) vector (Invitrogen) after enrichment by amplification from human testis cDNA with the primers: 19EAT, HFFP and HFFFA (Table 1). Restriction enzymes sites as well as the flag coding sequence, as indicated in Table 1 preceded the specific sequences in the primers. The inserted $\mathrm{i}_{19}$ VEGFR-1 coding region was then flanked by specific restriction sites, for polarity cloning into the vector, and tagged with the Flag sequence. The recombinants having the expected insert size, were confirmed by sequencing, and high quality DNA was prepared (Qiagen) for subsequent eukaryotic transfection.

\section{RT-PCR and quantitative real-time PCR}

Total RNA was reverse transcribed to cDNA with the iScript cDNA synthesis kit (BioRad) and specific primers, random nanomers or anchored oligo(dT). Manual (Ecogen) and semi-quantitative RT-PCR, was as previously described [20]. Real-Time PCR was performed with an ABI 7500. Specific primers expanding at least one exon were used (Table 1). Experiments where performed in duplicated, and repeated three times.

\section{Statistical analysis}

Values are expressed as mean and standard deviations. Comparisons were made by the Wilcoxon test. 


\section{Antibodies, SDS-PAGE, and western blotting}

Antibodies and blocking peptide. Anti-Flt-1 \#2893 (Cell Signalling); anti-Flt-1 (C-17): sc-316 (Santa Cruz) (blocking peptide, sc-316P Santa Cruz); anti-Src \#2108 (Cell Signalling); anti-phospho-Src (pY418) 44-660G (Invitrogen/Thermo Fisher Sc); anti-Fyn antibody FYN3 \#sc-16 (Santa Cruz); anti- $\beta$-actin A5316 (Sigma) (loading control); anti- $\alpha$-tubulin T6074 (Sigma) (loading control). See Table 2 for antibodies' additional details.

\section{Western blot}

Cells were collected $48 \mathrm{~h}$ after transfection and lysed in lysis buffer, subjected to NuPAGE ${ }^{\circledR}$ Novex ${ }^{\circledR}$ Bis-Tris gels and NuPAGE ${ }^{\circledR}$ MES SDS gels, blotted in Nitrocellulose membranes (ThermoFisher) and hybridized with specific antibodies as recommended. Results were confirmed after performing three independent experiments.

Total human normal testis protein was from Clontech, pooled from 18 adult males aged 19-64. Semen samples were extracted for protein using Chaps or $0.5 \%$ Nonidet P-40 lysis buffer.

Peptide competition. Anti-Flt-1 Antibody (Santa Cruz) was diluted in tris-buffered saline (TBS) with or without the competing peptide at $200 \mathrm{M}$ fold excess as recommended (Santa Cruz).

\section{Binding experiments}

Cells. CHO and HEK293 Cells (Dr. Carles Enrich, Faculty of Medicine, UB), HUVEC Cells (Dr. Teresa Royo, Faculty of Medicine, UB) were cultured in RPMI$10 \%$ FBS, DMEM-10\% FBS or supplemented Medium 200 (Gibco) respectively.

DNA constructs transfection. CHO cells or HEK293 cells were seeded in $100 \mathrm{~mm}$ culture plates (Corning) at a density of $3.5 \times 10^{6}$ cells/plate and cultured with RPMI-10\% FBS. Transfections were performed with Lipofectamine $^{\circledR} 3000$ Reagent (ThermoFisher) and $5 \mu \mathrm{g}$ of each recombinant DNA. GFP transfected cells were used as a control.

Affinity gel binding and sedimentation. Anti-Flag (DYKDDDDK) affinity gel from Biotools was used for protein capture and interaction analysis, as recommended. Briefly, proteins were extracted with $1 \%$ Triton X-100, and $500 \mu \mathrm{L}$ were allowed to interact with $10 \mu \mathrm{L}$ of uniformly resuspended anti-Flag affinity gel in $600 \mu \mathrm{L}$ Tris-buffered saline (TBS), for $2 \mathrm{~h}$ at $4^{\circ} \mathrm{C}$ and with gently agitation. Then, the resin was collected by centrifugation ( $30 \mathrm{sec}$ at $4,000 \mathrm{xg}$ ) and washed (3-5 times) with $0.5 \mathrm{~mL}$ of TBS till OD280 was $<0.05$. Elution was carried with $2 x$ SDS PAGE, boiled for 5 min and $4 \mu \mathrm{L}$ loaded in SDS-PAGE gels. The experiment was reproduced 3 times with independent samples.

\section{In silico analysis}

VEGFR-1 genomic sequences were analyzed for potential transcription factor binding sites using the
JASPAR software [42] for single sequences and Consite software [43].

CpG islands in the VEGFR-1 gene were predicted using DBCAT (DataBase of $\mathrm{CpG}$ islands and Analytical Tool) software [44].

DNaseI hypersensitivity in the VEGFR-1 locus was analyzed comparing against the ENCODE genomic region derived from assays in the cell line NT2-D1 cell [NTERA-2 cl.D1 [NT2/D1] (ATCC ${ }^{\circledR}$ CRL-1973) from testis, with the data deposited in the GenomeBrowser [45].

\section{Author contributions}

1. Ana Belen Alvarez-Palomo. Cell culture, transfections, protein electrophoresis and western blot, analysis of data and manuscript revision. 2. Carme Barrot. Real-time PCR array design, analysis and interpretation of data, revision and submission of final manuscript. 3. Helena Sarret. Protein affinity binding experiments, protein electrophoresis and western blots. 4. Jordi Requena. Statistical analysis and histogram construction. 5. Montserrat Pau. Valuable technical assistance. 6. JoseManuel Vidal-Taboada. Encode Project Consortium search and interpretation. 7. Rafael Oliva. Study design of patient samples and revision of manuscript. 8. Josep-Lluis Ballesca. Clinical responsibility for sample selection, information and consent. 9. Michael J Edel. Results discussion, interpretation and revision of english-language and content. 10. Jovita Mezquita-Pla. Intracellular $i_{19}$ VEGFR-1 and $\mathrm{i}_{28}$ VEGFR-1 transcript and protein identification, RACE5' and 3 ' characterization and sequencing, $i_{19}$ VEGFR-1-flag tagged recombinant construction and growth, northern blot analysis, RT-PCR, study design, interpretation of data, figures' drawings, table construction and manuscript writing and submission.

\section{ACKNOWLEDGMENTS}

Dr Juan Manuel Corral-Molina, Urology specialist (Hospital Clínic) and Dr Agustin Garcia-Peiró (UAB / Cimab) for kindly supplying informed samples. Ms. Montse Ortega, Faculty of Medicine, UB, for technical support. Dr Cristobal Mezquita, UB, Professor of Physiology, for valuable help in the initial writing of the manuscript. Dr Martin Rechsteiner, Distinguished Professor, University of UTAH School of Medicine, USA, for critical and valuable revision.

\section{Ethics statement}

All patients signed informed consent forms and all human material used was in accordance with the appropriate ethical and Internal Review Board guidelines of the Hospital Clinic from Barcelona. For all the experiments, only the surplus of the samples, which are normally discarded after routine assisted, were used. 


\section{CONFLICTS OF INTEREST}

The authors declare no conflicts of interest.

\section{FUNDING}

This study was supported by the University of Barcelona, MINECO project grant BFU2014-54467-P.

\section{REFERENCES}

1. Krawetz SA. Paternal contribution: New insights and future challenges. Nat Rev Genet. 2005; 6:633-642. https://doi. org/10.1038/nrg1654. [PubMed]

2. Lalancette C, Miller D, Li Y, Krawetz SA. Paternal contributions: New functional insights for spermatozoal RNA. J Cell Biochem. 2008; 104:1570-1579. https://doi. org/10.1002/jcb.21756. [PubMed]

3. Mezquita J, Mezquita C. Characterization of a chicken polyubiquitin gene preferentially expressed during spermatogenesis. FEBS Lett. 1991; 279:69-72. https://doi. org/10.1016/0014-5793(91)80253-y. [uㅏMed]

4. Mezquita J, Pau M, Mezquita C. Several novel transcripts of glyceraldehyde-3-phosphate dehydrogenase expressed in adult chicken testis. J Cell Biochem. 1998; 71:27-39. https:// doi.org/10.1002/(SICI)1097-4644(19981001)71:1<127::AIDJCB13>3.0.CO;2-K. [PubMed]

5. Kierszenbaum AL. Tyrosine protein kinases and spermatogenesis: Truncation matters. Mol Reprod Dev. 2006; 73:399-403. https://doi.org/10.1002/mrd.20456. [PubMed]

6. Sette C, Dolci S, Geremia R, Rossi P. The role of stem cell factor and of alternative c-kit gene products in the establishment, maintenance and function of germ cells. Int J Dev Biol. 2000; 44:599-608. [PubMed]

7. Sorrentino V, Giorgio M, Geremia R, Besmer P, Rossi P. Expression of the c-kit proto-oncogene in the murine male germ cells. Oncogene. 1991; 6:140-151. [PubMed]

8. Rossi P, Marziali G, Albanesi C, Charlesworth A, Geremia R, Sorrentino V. A novel c-kit transcript, potentially encoding a truncated receptor, originates within a kit gene introns in mouse spermatids. Dev Biol. 1992; 152:203-207. https://doi.org/10.1016/0012-1606(92)90172-d. [PubMed]

9. Albanesi C, Geremia R, Giorgio M, Dolci S, Sette C. A cell- and developmental stage-specific promoter drives the expression of a truncated c-kit protein during mouse spermatid elongation. Development. 1996; 122:1291-1302. [PubMed]

10. Koch S, Clesson-Welsh L. Signal transduction by vascular endothelial growth factor receptors. Biochem J. 2011; 437:169-183. $\quad$ https://doi.org/10.1042/BJ20110301. [PubMed]

11. Shibuya M, Yamaguchi S, Yamane A, Ikeda T, Tojo A, Matsushime H, Sato M. Nucleotide sequence and expression of a novel human receptor-type tyrosine kinase gene (flt) closely related to the fms family. Oncogene. 1990; 5:519-524. [PubMed]

12. Shibuya M. Vascular endothelial growth factor and its receptor system: Physiological functions in angiogenesis and pathological roles in various diseases. J Biochem. 2013; 153:13-19. https://doi.org/10.1093/jb/mvs136. [PubMed]

13. Terman BI, Carrion ME, Kovacs E, Rasmussen BA, Eddy RL, Shows TB. Identification of a new endothelial cell growth factor receptor tyrosine kinase. Oncogene. 1991; 6:1677-1683. [PubMed]

14. Barleon B, Sozzani S, Zhou D, Weich HA, Mantovani A, Marme D. Migration of Human Monocytes in Response to Vascular Endothelial Growth Factor (VEGF) Is Mediated via the VEGF Receptor flt-1. Blood. 1996; 87:3336-43. [PubMed]

15. Korpelainen EI, Karkkainen MJ, Tenhunen A, Lakso M, Rauvala H, Vierula M, Parvinen M, Alitalo K. Overexpression of VEGF in testis and epididymis causes infertility in transgenic mice: Evidence for nonendothelial targets for VEGF. J Cell Biol. 1998; 143:1705-1712. https:// doi.org/10.1083/jcb.143.6.1705. [PubMed]

16. Nalbandian A, Dettin L, Dym M, Ravindranath N. Expression of Vascular Endothelial Growth Factor Receptors During Male Germ Cell Differentiation in the Mouse. Biol Reprod. 2003; 69:985-994. https://doi. org/10.1095/biolreprod.102.013581. [PubMed]

17. Kondo K, Hiratsuka S, Subbalakshmi E, Matsushime H, Shibuya M. Genomic organization of the flt-1 gene encoding for Vascular Endothelial Growth Factor (VEGF) Receptor-1 suggests an intimate evolutionary relationship between the 7-Ig and the 5-Ig tyrosine kinase receptors. Gene. 1998; 208:297-305. https://doi.org/10.1016/s03781119(98)00006-7. [PubMed]

18. Kendall RL, Thomas KA. Inhibition of vascular endothelial cell growth factor activity by an endogenously encoded soluble receptor. Biochemistry. 1993; 90:10705-10709. https://doi.org/10.1073/pnas.90.22.10705. [PubMed]

19. Thomas CP, Andrews JI, Liu KZ. Intronic polyadenylation signal sequences and alternate splicing generate human soluble Flt-1 variants and regulates the abundance of soluble Flt-1 variants in the placenta. FASEB J. 2007; 21:3885-3895. https://doi.org/10.1096/fj.07-8809com. [PubMed]

20. Mezquita B, Mezquita J, Pau M, Mezquita C. A novel intracellular isoform of VEGFR-1 activates Src and promotes cell invasion in MDA-MB-231 breast cancer cells. J Cell Biochem. 2010; 110:732-42. https://doi.org/10.1002/ jcb.22584. [PubMed]

21. Cooper TG, Noonan E, von Eckardstein S, Auger J, Baker HW, Behre HM, Haugen TB, Kruger T, Wang C, Mbizvo MT, Vogelsong KM. World Health Organization reference values for human semen characteristics. Hum Reprod Update. 2010; 16:231-45. https://doi.org/10.1093/humupd/ dmp048. [PubMed]

22. Ma B, Pan Y, Zheng J, Levine AJ, Nussinov R. Sequence analysis of $\mathrm{p} 53$ response-elements suggests multiple binding modes of the p53 tetramer to DNA targets. Nucleic Acids 
Research. 2007; 35:2986-3001. https://doi.org/10.1093/nar/ gkm192. [PubMed]

23. Rajković M, Iwen KAH, Hofmann PJ, Harneit A, Weitzel JM. Functional cooperation between CREM and GCNF directs gene expression in haploid male germ cells. Nucleic Acids Res. 2010; 38:2268-2278. https://doi.org/10.1093/ nar/gkp1220. [ubMed]

24. Hariharan N, Perry RP. Functional dissection of a mouse ribosomal protein promoter: Significance of the polypyrimidine initiator and an element in the TATAbox region (transcription efficiency/initiation complex). Biochemistry. 1990; 87:1526-1530. https://doi.org/10.1073/ pnas.87.4.1526. [ [PubMed]

25. Morris DR, Geballe AP. Upstream Open Reading Frames as Regulators of mRNA Translation. Mol Cell Biol. 2000; 20:8635-8642. https://doi.org/10.1128/mcb.20.23.86358642.2000. [ [PubMed]

26. Fujii K, Shi Z, Zhulyn O, Denans N, Barna M. Pervasive translational regulation of the cell signalling circuitry underlies mammalian development. Nat Commun. 2017; 8:14443. https://doi.org/10.1038/ncomms14443. [PubMed]

27. Muehlenbachs A, Fried M, Lachowitzer J, Mutabingwa TK, Duffy PE. Natural selection of FLT1 alleles and their association with malaria resistance in utero. Proc Natl Acad Sci U S A. 2008; 105:14488-14491. https://doi.org/10.1073/ pnas.0803657105. [PubMed]

28. Muciaccia B, Sette C, Paronetto MP, Barchi M, Pensini S, D'Agostino A, Gandini L, Geremia R, Stefanini M, Rossi P. Expression of a truncated form of KIT tyrosine kinase in human spermatozoa correlates with sperm DNA integrity. Hum Reprod. 2010; 25:2188-2202. https://doi.org/10.1093/ humrep/deq168. [PubMed]

29. Sette C, Bblacqua A, Bianchini A, Mangea F, Geremia R, Rossi P. Parthenogenetic activation of mouse eggs by microinjection of a truncated c-kit tyrosine kinase present in spermatozoa. Development. 1997; 124:2267-2274. [PubMed]

30. Zhou Y, Sunt Z, Meanst AR, Sassone-Corsi P, Bernstein KE. cAMP-response element modulator $\mathrm{T}$ is a positive regulator of testis angiotensin converting enzyme transcription (cAMP-response element modulator/spermatogenesis). Biochemistry. 1996; 93:12262-12266. https://doi. org/10.1073/pnas.93.22.12262. [PubMed]

31. Yiu GK, Hecht NB. Novel testis-specific proteinDNA interactions activate transcription of the mouse protamine 2 gene during spermatogenesis. J Biol Chem. 1997; 272:26926-26933. https://doi.org/10.1074/ jbc.272.43.26926. [PubMed]

32. Martianov I, Choukrallah MA, Krebs A, Ye T, Legras S, Rijkers E, Van Ijcken W, Jost B, Sassone-Corsi P, Davidson I. Cell-specific occupancy of an extended repertoire of CREM and CREB binding loci in male germ cells. BMC Genomics. 2010; 11:530. https://doi.org/10.1186/14712164-11-530. [PubMed]
33. Giguere V, Tini M, Flock G, Ong E, Evans RM, Otulakowski G. Isoform-specific amino-terminal domains dictate DNA-binding properties of ROR $\alpha$, a novel family of orphan hormone nuclear receptors. Genes Dev. 1994; 8:538-553. https://doi.org/10.1101/ gad.8.5.538. [PubMed]

34. Connor F, Cary PD, Read CM, Preston NS, Driscoll PC, Denny P, Crane-Robinson C, Ashworth A. DNA binding and bending properties of the post-meiotically expressed Sryrelated protein Sox-5. Nucleic Acids Res. 1994; 22:3339-46. https://doi.org/10.1093/nar/22.16.3339. [PubMed]

35. Nelander S, Larsson E, Kristiansson E, Månsson R, Nerman O, Sigvardsson M, Mostad P, Lindahl P. Predictive screening for regulators of conserved functional gene modules (gene batteries) in mammals. BMC Genomics. 2005; 6:68. https:// doi.org/10.1186/1471-2164-6-68. [PubMed]

36. Hrabchak C, Varmuza S. Identification of the spermatogenic zip protein Spz1 as a putative protein phosphatase-1 (PP1) regulatory protein that specifically binds the PP1 cgamma2 splice variant in mouse testis. J Biol Chem. 2004; 279:37079-86. https://doi.org/10.1074/jbc.M403710200. [PubMed]

37. Montjean D, De La Grange $\mathrm{P}$, Gentien D, Rapinat A, Belloc S, Cohen-Bacrie P, Menezo Y, Benkhalifa M. Sperm transcriptome profiling in oligozoospermia. J Assist Reprod Genet. 2012; 29:3-10. https://doi.org/10.1007/s10815-0119644-3. [PubMed]

38. Baker MA, Hetherington L, Aitken RJ. Identification of SRC as a key PKA-stimulated tyrosine kinase involved in the capacitation-associated hyperactivation of murine spermatozoa. Journal of Cell Science. 2006; 119:31823192. https://doi.org/10.1242/jcs.03055. [PubMed]

39. André C, Martin E, Cornu F, Hu WX, Wang XP, Galibert F. Genomic organization of the human c-kit gene: evolution of the receptor tyrosine kinase subclass III. Oncogene. 1992; 7:685-691. [ubMed]

40. Hiratsura S, Minowa O, Kung J, Noda T, Shibuya M. Flt-1 lacking the tyrosine kinase domain is sufficient for normal development and angiogenesis in mice. Proc Natl Acad Sci U S A. 1998; 95:9349-9354. https://doi.org/10.1073/ pnas.95.16.9349. [ [PubMed]

41. De Mateo S, Martínez-Heredia J, Estanyol JM, Domínguez-Fandos D, Vidal-Taboada JM, Ballescà JL, Oliva R. Marked correlations in protein expression identified by proteomic analysis of human spermatozoa. Proteomics. 2007; 7:4264-77. https://doi.org/10.1002/ pmic.200700521. [PubMed]

42. Mathelier A, Zhao X, Zhang AW, Parcy F, Worsley-Hunt R, Arenillas DJ, Buchman S, Chen CY, Chou A, Ienasescu H, Lim J, Shyr C, Tan G, et al. JASPAR 2014: An extensively expanded and updated open-access database of transcription factor binding profiles. Nucleic Acids Res. 2014; 42:D142-147. https://doi.org/10.1093/nar/gkt997. [PubMed] 
43. Sandelin A, Wasserman WW, Lenhard B. ConSite: Webbased prediction of regulatory elements using cross-species comparison. Nucleic Acids Res. 2004; 32:W249-W252. https://doi.org/10.1093/nar/gkh372. [PubMed]

44. Kuo HC, Lin PY, Chung TC, Chao CM, Lai LC, Tsai MH, Chuang EY. DBCAT: Database of CpG Islands and Analytical Tools for Identifying Comprehensive Methylation Profiles in Cancer Cells. J Comput Biol. 2011; 18:1013-1017. https:// doi.org/10.1089/cmb.2010.0038. [PubMed]
45. Rosenbloom KR, Sloan CA, Malladi VS, Dreszer TR, Learned K, Kirkup VM, Wong MC, Maddren M, Fang R, Heitner SG, Lee BT, Barber GP, Harte RA, et al. ENCODE Data in the UCSC Genome Browser: Year 5 update. Nucleic Acids Res. 2013; 41:D56-63. https://doi.org/10.1093/nar/ gks1172. [PubMed] 